УДК 656.073.235

Д-р техн. наук А.М. Котенко, канд. техн. наук П.С. Шилаєв, аспирант А.В. Світлична

Doct. of techn. sciences A.M. Kotenko, cand. of techn. sciences P.S. Shylayev, postgraduate A.V. Svetlichnaya

\title{
ВИЗНАЧЕННЯ ДОЦІЛЬНОСТІ ТА МОДЕЛЮВАННЯ КОНТРЕЙЛЕРНИХ ПЕРЕВЕЗЕНЬ
}

\section{DETERMINATION OF FEASIBILITY AND MODELLING OF PIGGYBACK}

Постановка проблеми у загальному вигляді, іiі зв'язок 3 важливими науковими та практичними завданнями. У країнах Євросоюзу контрейлерні перевезення зростають випереджаючими темпами і складають 30 \% всіх залізничних вантажних перевезень. Основні вантажопотоки зосереджені на напрямках декількох транспортних коридорів, де діють більше 300 терміналів на території 29 країн. На території країн Євросоюзу здійснюється в цілому більше 21,5 тис. маршрутних контрейлерних відправок у рік. Зростанню обсягу контрейлерних перевезень сприяють i обмеження в русі вантажного автомобільного транспорту, введені в ряді країн 3 екологічних міркувань. Впровадження контрейлерних технологій у світі тісно взаємопов'язано 3 можливостями існуючої колійної та термінальної інфраструктури.

В Україні транспортна діяльність робить суттєвий внесок у створення валової доданої вартості (ВДВ): за даними
Державної служби статистики України, іiі частка становить $13 \%$, а вартість основних засобів виробництва (за первинною оцінкою) - $35 \%$ загальної вартості виробничого потенціалу країни, середньооблікова кількість штатних працівників галузі складає понад 935 тис. осіб. Комплексні заходи щодо розвитку транспортної галузі $\epsilon$ стратегічно важливими i передбачають реалізацію інфраструктурних і транспортних проектів, серед яких - реконструкція аеропортів, будівництво мостів, доріг, тунелів, розмежування пасажирських $\mathrm{i}$ вантажних залізничних маршрутів i запуск високошвидкісних поїздів у денний час, переоснащення портів, побудова ланцюга міжнародних логістичних центрів, подальша розбудова мережі міжнародних транспортних коридорів (МТК), які забезпечували б ефективніше сполучення між Європою та Азією територією України.

Аналіз останніх досліджень i публікацій. Питання ефективності 
контрейлерних перевезень i питомих капіталовкладень в основні та обігові засоби досліджував Г.М. Кірпа [4]. Він довів, що необхідно враховувати низку чинників, а 3 врахуванням лише кількох критеріїв не можна отримати однозначного рішення. Питанням розвитку контрейлерних перевезень присвячена велика кількість наукових робіт, статей [3, 6,8, 9]. У роботі [1] наводяться ресурсозберігаючі технології виконання вантажних операцій 3 напівпричепами, причепами, вантажними модулями. У роботах $[5,7,11]$ виконується розрахунок ефективності комбінованих перевезень, проаналізовано застосовувані у світовій практиці контрейлерні технології.

Метою роботи с визначення доцільності та моделювання контрейлерних перевезень, розрахунок вартості перевезення «мертвої ваги», що перевозиться разом із вантажним модулем при контрейлерних перевезеннях.

Виклад основного матеріалу. Щодо розвитку контрейлерних перевезень в Україні слід відмітити поїзд «Вікінг», призначений для перевезення 20- і 40футових контейнерів, напівпричепів та автопоїздів. 319 січня 2012 р. поїзд комбінованого транспорту «Вікінг» почав регулярне курсування три рази на тиждень по маршруту Одеса/Іллічівськ - Бережесть (Україна) - Словечине/Мінськ - Гудогай (Білорусь). Крім спеціальних платформ для перевезення контейнерів і автопоїздів, до складу поїзда входять спальні вагони, вагон-ресторан, вагон для технічного персоналу. Об'єми комбінованих перевезень поїздом «Вікінг» залізницями України у 2012 р збільшилися в 3.9 разу до 13.9 тис. TEU (у 2011 p. - 3.6 тис. TEU).

Контрейлерні перевезення - це перевезення визначеними маршрутами автопоїздів, автопричепів, автомобілів, напівпричепів, знімних автомобільних кузовів (у навантаженому або порожньому стані) завантажених одним відправником на станції відправлення на адресу одного одержувача на одну або декілька станцій призначення без переробки на шляху прямування на сортувальних станціях.

До переваг комбінованого транспорту можна віднести:

- високу швидкість і гарантію доставки вантажів відповідно до графіка руху поїзда (just in time);

- безпеку перевезення за будь-яких погодних умов;

- скорочення часу проходження прикордонного та митного контролів;

- збереження транспортного засобу та економію палива;

- збереження автомобільних доріг;

- збереження навколишнього середовища;

- зниження ймовірності дорожньотранспортних випадків (ризик виникнення нещасного випадку на залізниці в 40 разів нижчий за автомобільний, що особливо важливо для перевезення небезпечних вантажів);

- поліпшення обміну обсягів перевезень між видами транспорту.

Ефективність контрейлерних перевезень слід очікувати від скорочення обороту платформ, локомотивів, скорочення порожнього пробігу рухомого складу, економії експлуатаційних витрат, пов'язаних 3 формуванням складів, підвищення надійності й ефективності транспортних послуг. Собівартість перевезень і питомі капітальні вкладення в основні і обігові кошти - одні з основних чинників, що впливають на вибір транспорту для вантажних перевезень.

На основі аналізу технічних характеристик контрейлерів і знімних кузовів, термінального обладнання для переробки контрейлерів, режимів роботи контрейлерних поїздів виконано технікоекономічні розрахунки контрейлерних перевезень залежно від дальності перевезень, враховуючи різні витрати. Однією з основних переваг, яка зумовлює вибір контрейлерного способу доставки вантажів вітчизняними та зарубіжними 
перевізниками, є значно нижча собівартість цих перевезень порівняно 3 автомобільними.

Економічну доцільність контрейлерних перевезень можна визначити порівнянням вартостей виконання перевантажувальних операцій на станціях відправлення і призначення та вартості перевезення «мертвої ваги» - тари вантажного модуля, двох «класних» (пасажирських) вагонів для проїзду водіїв та іншого персоналу, як

$$
E_{\text {nep }}=\sum W_{\text {n.M.6. }}
$$

де $E_{n е p}-$ вартість перевантажувальних операцій на станціях відправленняпризначення, грн;

$\sum W_{\text {n.м.в. }}{ }^{-} \quad$ вартість перевезення «мертвої ваги», грн.

$$
E_{n e p}=g\left(n_{b} \cdot C_{1}+n_{n p} \cdot C_{2}\right),
$$

де $g$ - масса вантажу, що переміщується одним вагоном , т;

$n_{6} ., \quad n_{n p}-$ кількість вантажних операцій, що виконується відповідно на станціях відправлення і призначення 3 вантажем, од;

$C_{1}, C_{2}-$ вартість виконання вантажних операцій 3 однією тонною вантажу на станціях відправлення та призначення, грн.

Витрати на перевезення «мертвої ваги» залізничним транспортом можна визначити так.

Коефіцієнт співвідношення маси «мертвої ваги» і загальної маси в контрейлері визначається як

$$
\gamma=\frac{M_{\mathcal{M . M . 6}}}{M_{\text {3.M.в. }}} .
$$

Вартість перевезення «мертвої ваги» $\sum W_{\text {n.м.в. }}=W_{1}+W_{2}+W_{3}+W_{4}+W_{5}+W_{6}$,

де $W_{1}-$ витрати, пов'язані зі стоянкою АТЗ (автомобільного транспортного засобу), охороною на терміналі:

$$
W_{1}=\gamma \cdot\left(b_{c m} \cdot t_{c m}+b_{n \kappa}+b_{B H}\right) \cdot\left(T_{a}+P_{a}\right),
$$

де $b_{c m}$ - витрати пов'язані з утриманням складів і зберіганням вантажів на терміналі, грн/тдоб;

$t_{\mathrm{cm}}-$ середня тривалість знаходження автомобіля (вантажу) на терміналі до відправлення поїзда, доб;

$b_{n \kappa^{-}}$витрати, пов'язані початковокінцевими операціями на терміналі, грн/т;

$b_{8 H}-$ витрати, пов'язані 3 вантажними операціями на терміналі, грн/т;

$T a-$ маса тари автопоїзда, т;

$P_{a}-$ середнє навантаження автопоїзда, нетто, т;

$W 2^{-}$витрати, пов'язані з утриманням спеціального рухомого складу

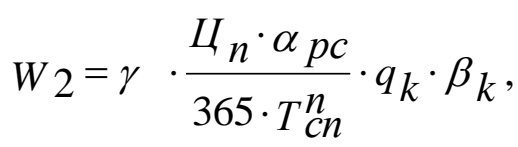

де $\zeta_{n}$-ціна спеціальної платформи, грн;

$T_{c n}^{n}-$ строк служби спецплатформи, роки;

$q_{k}$ - оборот контрейлерного поїзда, доб;

$\alpha_{p c}-$ коефіцієнт, що враховує вартість усіх ремонтів спец платформи протягом іiі служби;

$\beta_{k}-$ коефіцієнт, що враховує наявність у поїзді пасажирських вагонів для проїзду водіїв та іншого персоналу;

$W_{3}$ - витрати на охорону контрейлерного поїзда на всьому рейсі курсування маршруту 


$$
W_{3}=\gamma \cdot\left(b_{3 n}^{k}+\frac{b_{d}^{i}+b_{\partial}^{y}}{2}\right) \cdot \frac{q_{k} \cdot u_{k}}{n_{c n}},
$$

де $b_{3 n}^{k}-$ середньодобова заробітна плата (3 нарахуванням) стрілка караулу, грн/доб;

$b_{\partial}^{i}$ - добові при відрядженні на території іноземних держав, грн/доб;

$b_{\partial}^{y}$ - добові при відрядженні на території України, грн/доб;

$q_{k}$ - оборот контрейлерного поїзда, доб;

$u_{k}-$ чисельність караулу, люд;

$n_{c n}{ }^{-}$кількість спец платформ у контрейлерному поїзді, од;

$W_{4}$ - витрати на операції під час руху та обслуговування постійних пристроїв залізниць,

$$
W_{4}=\gamma \cdot b_{n p} \cdot\left(T_{B}+T_{a}+P_{a}\right) \cdot \beta_{k} \cdot L,
$$

де $b_{n p}$ - витрати, пов'язані з переміщенням вагона 3 вантажем і утриманням постійних пристроїв залізниці, грн/тдоб;

$T_{B}-$ маса тари вагона (спецплатформи), $\mathrm{T}$;

$T_{a}$ - маса тари автопоїзда, т;

$P_{a}$ - середнє навантаження автопоїзда, нетто, т;

$\beta_{k}$ - коефіцієнт, що враховує наявність в поїзді 2x-класних (пасажирських) вагонів для проїзду водіїв та іншого персоналу;

$L$ - відстань перевезення, км.

$W 5^{-}$витрати на обслуговування контрейлерного поїзда на технічних станціях.

$$
W_{5}=\gamma \cdot b_{\text {mex }} \cdot\left(T_{6}+T_{a}+P_{a}\right) \cdot \beta_{k} \cdot \frac{L}{L_{\text {mex }}},
$$

де $b_{\text {mex }}$ - витрати, пов'язані 3 переміщенням вагона 3 вантажем i утриманням постійних пристроїв залізниці, грн/тдоб;

$T_{6}-$ маса тари вагона (спецплатформи), $\mathrm{T}$;

$T_{a}$-маса тари автопоїзда, т;

$P_{a}$ - середнє навантаження автопоїзда, нетто, т;

$\beta_{k}$ - коефіцієнт, що враховує наявність у поїзді пасажирських вагонів для проїзду водіїв та іншого персоналу;

$L$ - відстань перевезення, км;

$L_{m e x}-$ середня відстань між технічними станціями (гарантійне вагонне плече), км.

$W_{6}$ - витрати на оплату роботи поїзних локомотивів,

$$
W_{6}=\gamma \cdot\left(\frac{b_{\pi 2}}{V} \cdot b_{л \kappa M}\right) \cdot \frac{L_{y}}{n_{c n}},
$$

де $b_{л 2}-$ собівартість локомотиво-години, грн/лок.год;

$V$ - маршрутна швидкість по Україні, км/год ;

$b_{\text {лкм }}{ }^{-}$собівартість локомотивокілометра, грн/лок.км;

$n_{c n}{ }^{-}$кількість спецплатформ у контрейлерному поїзді, од;

$L y-$ відстань пробігу по Україні, км;

Математична модель руху контрейлерного поїзда $\mathrm{y}$ вигляді графа станів подана на рис. 1. 


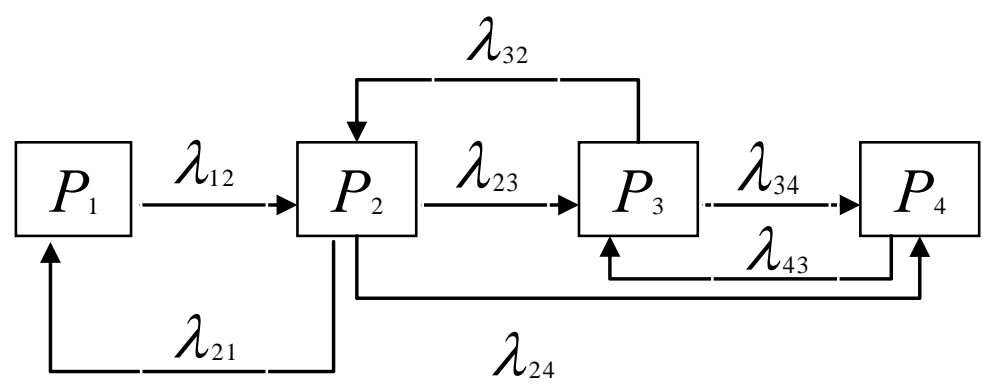

Рис. 1. Граф станів контрейлерного поїзда:

$P_{1}-$ під вантажними операціями; $P_{2}-$ на шляху прямування;

$P_{3}-$ на технічних станціях; $P_{4}-$ на передавальних станціях

Система диференціальних рівнянь Колмогорова для графа (рис. 1)

$$
\left.\begin{array}{l}
\frac{d P_{1}}{d t}=-\lambda_{12} P_{1}+\lambda_{21} P_{2} \\
\frac{d P_{2}}{d t}=-\lambda_{23} P_{2}-\lambda_{24} P_{2}-\lambda_{21} P_{2}+\lambda_{32} P_{3}+\lambda_{12} P_{1} \\
\frac{d P_{3}}{d t}=-\lambda_{34} P_{3}-\lambda_{32} P_{3}+\lambda_{23} P_{2}+\lambda_{43} P_{4} \\
\frac{d P_{4}}{d t}=\lambda_{34} P_{3}-\lambda 43 P_{4}
\end{array}\right\}
$$

Нормувальна умова

$$
P_{1}+P_{2}+P_{3}+P_{4}=1
$$

Вірогідність станів руху контрейлерного поїзда залежно від часу наведена на рис. 2.

Висновки 3 досліджень i перспективи, подальший розвиток у даному напрямку. При використанні контрейлерного способу доставки досить відчутним $\epsilon$ економічний ефект роботи транспорту, значно скорочуються витрати 3 транспортування товарів. Наведена модель руху контрейлерного поїзда у вигляді графа станів i диференціальних рівнянь дає можливість визначити оптимальні режими руху на шляху прямування та на терміналах вантажних станцій. Реалізація регулярного контрейлерного сполучення забезпечить розвиток мережі існуючих транспортних коридорів, інтеграцію транспортної інфраструктури України до світової транспортної системи. 

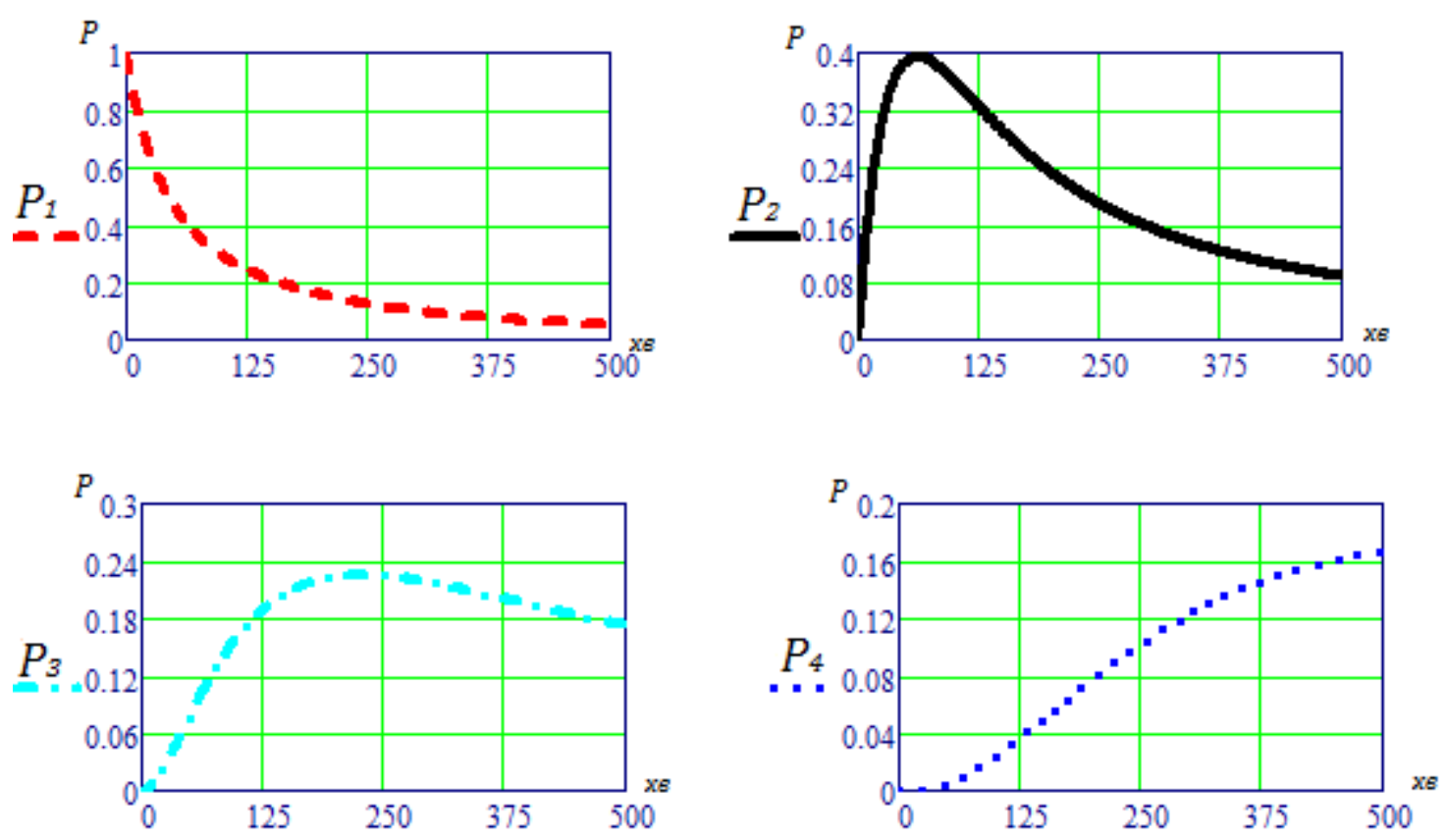

Рис. 2. Вірогідність станів руху контрейлерного поїзда залежно від часу

\section{Список літератури}

1. Шилаєв, П.С. Підвищення ефективності процесу інтероперабель-них перевезень вантажів на основі ресурсозберігаючих технологій [Текст]: автореф. дис. канд. техн. наук: 05.22.01 / П.С. Шилаєв. - Харків, 2012. - 20 с.

2. Котенко, А.М. Інтермодальні перевезення. Перспективи розвитку [Текст] / А.М. Котенко, П.С. Шилаєв // Зб. наук. праць. - Харків: УкрДАЗТ, 2009. - Вип.54. - С. 31-36.

3. Шапкин, А.С. Выбор технико-технологических параметров сис-темы контрейлерных перевозок на железнодорожных направлениях сети. [Текст]: автореф. дис. канд. техн. наук: 05.22.08 / А.С. Шапкин. - М., 2005. - 23 с.

4. Кирпа, Г.Н. Организация контрейлерных перевозок в Украине [Текст] / Г.Н. Кирпа.- Днепропетровск: Арт-Пресс, 1998. — 131 с.

5. Специальный выпуск Контрейлерные перевозки [Текст]: ООО «Редакция журнала «РЖД-партнер». - М., 2012. - 64 с.

6. Modalohr - система перевозки автотранспортних средств [Текст]: Железные дороги мира.- 2002. - № 10. - С. 44 - 46.

7. Гапанович, В.А. Об организации контрейлерных перевозок на «пространстве 1520» [Текст] / В.А. Гапанович // Железнодорожній транспорт.- 2012. - № 6. - С. 30 - 35.

8. Котенко, А.М. Підвищення ефективності комбінованих переве-зень. Удосконалення вантажної і комерційної роботи на залізницях України [Текст] / А.М. Котенко, В.Г Кушнірчук // Зб. наук. праць. -Харків: УкрДАЗТ, 2004. - Вип. 62. - С. 50-55.

9. Костюк, М.Д. Техніко-технологічне забезпечення інтермодальних та інтеропереробальних перевезень [Текст] / М.Д. Костюк, Ю.В. Дьомін // Залізничний транспорт України. - 2009. - № 3. - С. 3 - 7.

10. Сич, Є.М. Економічні аспекти контейнерно-контрейлерного об- слуговування клієнтури залізничного транспорту [Текст] / Є.М. Сич, Н.І. Богомолова, М.М. Андрієнко, В.М. Кислий. - К., 2007. - 391 с. 
11. Кизимиров, М.В. Экономическая оценка применения сочле-ненных платформ для перевозки трейлеров [Текст] / М.В. Кизимиров // Экономика железных дорог. - 2012. - № 10. - С. $75-79$.

Ключові слова: контрейлерні перевезення, доцільність, «мертва вага», моделювання, граф станів, диференціальні рівняння.

\section{Анотації}

У статті визначено доцільність контрейлерних перевезень і вартість перевезення «мертвої ваги», виконано моделювання контрейлерних перевезень. Наведено модель руху контрейлерного поїзда у вигляді графа станів і диференціальних рівнянь.

В статье определена целесообразность контрейлерных перевозок и стоимость перевозки «мертвого веса», выполнено моделирование контрейлерных перевозок. Приведена модель движения контрейлерного поезда в виде графа состояний и дифференциальных уравнений.

In this article the feasibility of piggyback and the cost of transportation of the "dead weight" have been determined, the modeling of piggyback have been done. The model of the motion of piggyback train as a graph of states and differential equations have been reduced. 